"Go and teach this man some sense of responsibility. Go and tell him we are tired and fed up, and if the Service does not break down by April we shall break down before it." The speeches were excellent, but the minds of the representatives were made up, and their feelings had to come out. "Let us press on regardless and then go back to the Representative Body and say, "This is what you told us to do. This is what we have been able to do, and this is what we have been unable to do.' I think the Representative Body would be shocked themselves if we did not do this," Dr. Gibson concluded.

Dr. R. B. L. RIDGe said that the essential feature of the existing situation was work load, but work load was not a basic principle in the issue. It was the sum of two factors -demand by individual patients and manpower. If there were unlimited manpower, no matter what the demand of patients might be, there would not be an excessive work load. But at the moment there were both factorsan increasing demand by patients and diminishing manpower, and the Committee's attention should be directed to both those factors and not to one.

Patient demand was a function of the degree of patient responsibility. In a material age value, regrettably, was determined in terms of money. "I have come to the inescapable conclusion that the ultimate choice which this country has to face is that between a fee paid by the patient at the time or the end of the independent general practitioner concept," said Dr. Ridge. "This is a decision that the country will have to take, but I am certain at the present moment neither the profession nor the politicians nor the public are ready to make this choice. If we take a decision now ourselves, either through a referendum or in any other way, we shall provoke a decision and it will go against us. This is the importance of taking a tactical decision against the whole strategical background."

Dr. Ridge was sure that the gist of the motion before the Committee showed the right way to proceed. The Minister had to say how he would alter the conditions of service and remuneration of general practice in this country to put it on a competitive basis with the remainder of the world. With regard to the difficulty facing the negotiators in devising alternative methods of remuneration, Dr. Ridge did not believe that the Charter contained the right formula. It asked for alternative methods of remuneration for one type of contract. What was wanted were different types of contract which would bring them particular methods of remuneration.

Dr. HAPPEL suggested that the question of a deterrent must loom larger than previous speakers had led the Committee to believe. If it brought a head-on clash with the
Government he would much rather it was on the general need for a charge than on the specific point of a consultation fee. If the doctors stuck to a general charge, however it might be applied, and supported it with the evidence of an increase in the number of prescriptions, they would eventually win through. He agreed that any decision should be delayed until the whole picture could be seen, including the pricing of the contract.

Dr. A. Elliot thought that general practitioners were not prepared to resign at the present time on the issue of payment by patients. Dr. Ridge had been right to suggest that the matter must be looked at against the background of what was going on. It was not only a question of a shortage of doctors throughout the world. Attention had also to be paid to what was going on in this country outside medicine. The Government had declared that there would have to be cuts in the social services, including the N.H.S. It could be that the Government, faced with economic difficulties, might welcome the breaking off of negotiations and find it very convenient to blame the medical profession. Responsibility must be placed where it belonged.

Dr. A. D. STOKER thought that a payment by the patient would not reduce the work load. As a dispensing doctor he found collecting the prescription charges had added thirty minutes to each surgery. "Let us proceed with our negotiations," he said, " and when we have completed the Charter take it to our constituents for acceptance or rejection."

\section{Personal List}

Dr. C. J. Wells said that a number of colleagues whom he had consulted were not in favour of resignation on the issue under discussion. The horrors of the present service were all inherent in the personal list. The personal list did not exist before 1948 except for a very small number of the population, and it was limited by income. The idea of personal service between doctor and patients was not something magical which appeared with the introduction of the N.H.S. Dr. Wells thought there was a great danger that unless there was an item-of-service payment by the patient at the time independent general practice as it was understood would die. Furthermore, one of the alternative methods of remuneration in the Charter was that of salary, and it was known that the Ministry was dedicated to a salaried service and would do all it could to introduce such a service combined with a personal list of patients. The Minister had refused to take any responsibility at all in the education of patients.

Dr. A. ReEves said that payment by the patient was not an issue on which the majority of his constituents would resign.
The policy of the Committee should be that embodied in Dr. Miller's motion, which he supported.

Dr. H. S. Howie Wood suggested that the Committee should consider holding a referendum of a non-inflammatory nature which would keep the profession entirely up to date with what was happening. It could be along the lines of seeking the doctors' approval of negotiations continuing on the broad principles of the Charter, notwithstanding the refusal of the Minister to entertain any payment by the patient.

Dr. WAND suggested that the Committee might consider the following as a rider to the motion: "The Committee has also received a letter from the Ministry on the problem of the work load of general practitioners. The Committee regards the suggestions offered by the Ministry as unrealistic and unlikely to provide a solution of this problem, which could reach considerable magnitude during the coming winter, and has instructed the negotiators to pursue the matters contained in the letter as a matter of urgency and report to the Committee."

\section{Amendment Moved}

Dr. J. C. Knox moved, and Dr. Heath seconded, by way of amendment, "That payment by the patient at the time of receiving a service with subsequent whole or partial reimbursement by the Government be one of the ways of implementing the item-of-service method of remuneration in the Charter."

Dr. H. N. Rose suggested that the Committee was deceiving itself and trying to deceive the profession The West Sussex resolution had been passed by a two-thirds majority, and in his view insufficient account had been taken of it. If the Committee lightly dismissed the opinion expressed in the resolution it would be guilty of a serious error. There were many members who believed that the resolution had not the backing of the whole profession, but they were not certain. There were ways of finding out, including a Special Representative Meeting or a postal vote, and Dr. Rose submitted that the Committee should not proceed any further until it had the information.

After some further debate, Dr. J. KNox agreed to withdraw his amendment with the permission of the seconder.

The amendment was, by leave, withdrawn.

The motion, moved by Dr. Miller and seconded by Dr. HAPPEL, was carried nem. con.

The Committee also adopted the words suggested by Dr. WAND as a rider.

( $A$ report of the remainder of the Committee's proceedings will be printed next week.)
Association Notices

\section{Diary of Central Meetings}

AUgust

17 Tues. Junior Members Forum Advisory Committee, 2 p.m. SEPTEMBER

2 Thurs. Joint Formulary Committee, 10.30 a.m.

3 Fri. Chest Clinics Subcommittee (C.C. and S. Committee),

10 a.m.

3 Fri. Dental Formulary Committee, 2 p.m.
Correction.-By agreement between the West Essex and Winchester Divisions, Dr. S. C. C. Scott (West Essex) moved the Winchester motion (217) on maternity fees at the Annual Representative Meeting and not the West Essex motion (216) as reported (Supplement, 24 July, p. 73). The Winchester motion, which was carried, was as follows: "That the present fees for maternity medical services are grossly inadequate." 